\title{
Die Bybel: Teks en ondermyning
}

\author{
Philip J Nel \\ Departement Nabye Oosterse Studie \\ Universiteit van die Vrystaat
}

\begin{abstract}
The Bible: Text and subversion

This article explores both the subversive dimension of the biblical text, in particular the Old Testament, as the ramifications thereof for the concept of a religious text. It argues that interpretation has been historically and fundamentally part and parcel of the genesis and reception history of the biblical text. The texts of Job and Jonah have been chosen for their explicit subversive strategies. The article shows that if the biblical text exploits strategies of subversion, it also contravenes the traditional opinion subscribing to a referential meaning of texts. A subversive text cannot simultaneously deny and confirm a constant (fixed) and an immutable reality. The article argues that biblical scholars should reconsider other perceptions of the religious text to avoid the destructive criticism of referential meaning in postmodern studies. One option to be considered is the view of a text as performative communication.
\end{abstract}

\section{INLEIDING}

In hierdie artikel word die ondermynende dimensie van Bybeltekste (by name die Ou Testament) ontleed en verreken ten opsigte van die begrip van religieuse teks. Daar word geargumenteer dat interpretasie nie 'n sekondêre dimensie van die Bybelteks is nie, maar in fundamentele en historiese sin altyd deel was van die wordings- en resepsiegeskiedenis van dié teks. Die tekste van Job en Jona word geanaliseer ten opsigte van die subversiewe karakter daarvan. Die konsekwensies van die aanwesigheid van subversiewe tekste word dan verreken ten opsigte van die begrip van religieuse teks en die tradisionele siening van verwysende betekenis. Daar word geredeneer dat 'n siening van verwysende tekstuele betekenis bots met die aanvaarding van subversiewe tekste en dat na 


\section{Die Bybel: Teks en ondermyning}

ander sienings van teks beweeg moet word wat die vernietegende kritiek van die postmodernisme teen verwysende betekenis kan ontsnap. 'n Voorlopige uitweg word aangedui in die rigting van die performatiewe aard van tekste.

\section{BEOOGDE ONTWERP}

Met hierdie artikel word gepoog om die kompleksiteit van die teks van die Bybel sodanig te ontgin om tot klaarheid te kom oor die vraag of die Bybelteks sigself kan ondermyn of subversief kan wees. Indien dit wel die geval is, moet die implikasies deurgetrek word na die begrip van teks of religieuse teks. Die aansluitende vraag is dan verder of ondermynende tekste ten opsigte van mekaar na 'n ideale of konstante werklikheid kan verwys. Op hierdie voorlopige stadium kan genoem word dat die Bybel nie 'n onveranderlike struktuur van die werklikheid kommunikeer nie, maar diskoerse oor aspekte van die werklikheid voer waarvan die sin in deelname en dialoog daarmee setel.

Ek wil graag aansluit by die heersende mediadebat oor die sogenaamde Nuwe Hervorming - nie dat ek enige begeerte het om daarop in te speel nie, meer as bloot te kyk na teksbegrippe wat hier na vore kom. Dié soort teksbegrip word dan gekontrasteer met 'n begrip van teks wat die tradisies van die Bybel kenmerk, veral die Rabbynse tradisie. Daarna word die tekste van Job en Jona behandel as ondermynende eksemplare van ander Bybeltekste. Hieruit word dan 'n uitweg uitgespel wat weer sal aansluit by die Rabbynse tradisie in meer moderne idioom.

\section{DIE TEKS VERWYS?}

In die openbare mediadebat oor die sogenaamde Nuwe Hervorming gaan dit meestal oor hoe verskillende persone die teks interpreteer. Spangenberg (Rapport, 23/6/2002) reken byvoorbeeld dat die beeld van die vertelde Jesus (hoe die tekste hom kommunikeer) nie gelyk gestel kan word aan die historiese Jesus nie al lees mense van die Christelike tradisie die teks-Jesus (karakter) as die historiese Jesus. Verseker is daar 'n verskil, net soos wat daar 'n verskil is tussen die God van die Ou Testament wat in verhale 'n personage van 'n 
sprekende karakter kan aanneem, wat tog sekerlik verskil van wat God eintlik is. Dit is waarom Jaap Durand (Die Volksblad, 25/9/2002) dan ook sê dat God 'n metafoor is omdat die metafoor in een opsig sê dit is so, maar tegelykertyd ook die teendeel sê: God is nie net die sprekende karakter nie.

Hierdie soort verskille van intepretasie sal daar altyd wees. Minder selde kry mens in die polemiek ' $n$ aanduiding van die teksbegrip wat hanteer word. Potgieter (Die Volksblad 13/6/2002) bepleit die onfeilbaarheid van die Bybel as Woord van God op grond van die primêre outeur (God self) se intensie, al word feilbare mense daarvoor gebruik. Die Woord het onfeilbaar oorgekom. As hy dan die teksbegrip verder wil belig, verval hy weer in die interpretasie van die inhoud daarvan, deur byvoorbeeld te sê dat die opgaaf van enige interpreteerder moet wees om die oorspronklike bedoeling vir die eerste hoorders vas te stel. Van Rensburg (Die Volksblad, 19/9/2002) stel dit nog meer pertinent dat daar 'n regte verstaan van die Skrif is "omdat die Heilige Gees die primêre outeur is. Die heilige Gees se bedoeling kan nooit relatief gemaak word tot ons eie(willige) interpretasie van die teks nie". [Hoe van Rensburg die bestaande realiteit van verskil van interpretasie met so 'n standpunt sou verklaar, sal niks minder as 'n deus ex machina verg nie.] As die hermeneutiese vraag hierby sou stop, dan het ons in terme van teksbegrip alleen die hele literatuurteoretiese debat sedert die Dertigs gemis en moet die empiriese realiteit van verskillende denominasies en gevarieerde interpretasies van die Bybel binne dieselfde denominasie die ongemaklikste versweë waarheid wees.

As die teks van die Bybel soos hierbo opgevat word, dan verwys die teks via die taal daarvan na 'n vaste en konstante werklikheid buite die teks. Die toeganklike taal is dan die venster op hierdie werklikheid sonder dat die taal self in die weg kan staan. As dit die geval sou wees, dan is ons eintlik nog 'n treëtjie verder weg van Plato, wat minstens nog verreken het dat taal die werklikheid op 'n onvolkome wyse naboots. Die skrywer is eintlik 'n tweederangse kunstenaar naas die vakman wat in werklikheid iets kan skep wat korreleer met die perfekte idee daarvan. 
Taal kan op geen wyse die werklikheid ideaal spieël of naboots nie. Daar is nie 'n perfekte huwelik tussen taal en die wêreld moontlik nie. Rorty en Fish ${ }^{1}$ sal sê dit is onmoontlik dat 'n mens kan uitbreek of ontkom aan taal om seker te maak dat ons woorde korrespondeer met die wêreld. Taal verwys in eintlike sin na niks meer as na ander taaltekens nie, maar minstens nie na 'n wêreld buite die taal self nie. Taal mag ons werklikhede struktureer en kan die apparaat wees waarmee ons verskillende oogmerke kan bereik. Fish trek dan die verdere konsekwensie dat tekste reeds die resultaat van ons interpretatiewe oogmerke is en dat die leser en ' $n$ interpreterende gemeenskap telkens teks voorafgaan. Die finale nekslag vir die debat dat tekste en taal buite hulleself na die wêreld verwys, het van Derrida (1978) gekom wat in aansluiting by Nietzsche taal en teks sien as 'n speelveld van interpretasie en dat tekste niks anders is as "verbale skyfies" nie (vgl Degenaar 1995:1-21). Die teks kan nooit buite sigself verwys nie, en om van die werklikheid van 'n outeur te praat is onmoontlik. Daar is daarom niks buite die teks nie. Die verskil van taaltekens is hul verskil ten opsigte van mekaar en hierdie verskil maak dit moontlik dat tekens nie dieselfde gelees word nie.

Ek haal baie kursories en erg oorvereenvoudig hierdie debat aan oor die moontlikheid of tekste en taal kan verwys na wêrelde buite hulself net om te wys dat as die hermeneutiek die teks van die Bybel wil red deur outeursintensie en die verwysende moontlikheid van die teken buite sigself te beklemtoon, dan loop hy hom vas teen die postmoderne debat. Hierdie debat verklaar die verwysing van tekens onmoontlik (bo en behalwe die verskil ten opsigte van mekaar) en daarom ook die outeur dood. As outeur en outeursintensies dan dood verklaar is, het dit ook die konsekwensie vir die Bybel dat God of die Heilige Gees as outeur dood verklaar word (vgl Vanhoozer 1988:66-73). Die teologie sal daarom baie ernstig die debat moet neem en nie die skietgoed verskaf waarvan die gevolge nie verreken word nie. Die teksbegrip van die voor- en teenstanders van die Nuwe Hervorming ontsnap nie aan die semiotiek van verwysende betekenis nie, en is op 'n kru manier die kanonvoer vir die Derridaanse debat.

\footnotetext{
${ }^{1}$ Fish se epogmakende werk (1980), Is there a text in this class? The authority of interpretative communities, het finaal die outoriteit van die outeur ontneem as 'n organiseerder van betekenis in ooreenstemming met 'n werklikheid, ten gunste van die "interpreterende gemeenskap" wat betekenis organiseer in talige tekste.
} 


\section{INTERPRETASIE AS DEEL VAN TEKS}

Op een of ander manier het die Christelike tradisie 'n aversie in die verskil van intepretasie van die Bybel opgebou. Verskil word bedreigend beleef. Dit hang waarskynlik saam met ons Grieks-Christelike tradisie waarin die teksteken vaste verwysings gekry het en dat al die Bybeltekens die vleesgeworde Woord moes "beteken". In werklike en metaforiese sin het die woord vlees geword: al die taaltekens van die Bybel moes daarheen wys, al is dit dan nie in letterlike sin nie, dan wel in allegoriese of geestelike sin. Die hermeneutiek van die Kerkvaders het op verskillende wyses, maar met dieselfde oogmerk, die finale verwysing van die taalteken probeer vasstel. ${ }^{2}$ Die gereformeerde dogmatiese tradisie het verder die finale verwysing van die taaltekens in dogmas vasgevang, soveel so dat hierdie dogmas in ortodokse kringe op elke leeshandeling beslag lê.

Tog was die teks wat ons vandag as die Bybel ken aanvanklik sonder dogmas, maar omgewe met interpretasie as inherente deel daarvan. Die Bybel is self manifestasie van die historiese proses van interpretasie. Interpretasie was die meegaande proses van tekswees en is eers werklik gekompromitteer met die finale debatte van die Kerkvaders rondom die kanonisering in die vroeë Middeleeue (vgl Barrera 1998:490-542). Hierdie proses van kanonisering is volgens Deist (1995:66-78) ook deur en deur ideologies.

In die Ou Testament self is daar strata en trajekte van tekste en teksinterpreterende tradisies. Die monargale geskiedenis word anders deur die Deuteronomis (Samuel en Konings) vertel as die Kronis (Kronieke). Die God van die Deuteronomis verskil van die God van die Kronis. Die Deuteronomis se idee van die staat en kultus verskil van die Kronis s'n. In die Deuteronomis se weergawe (2 Sam 24:1) is God David se aanhitser tot die volkstelling, maar in die Kronis se weergawe (Kron 21:1) is dit Satan.

2 Die interpretasies van die vroeë Kerkvaders is tekenend van die vaste verwysings van die OuTestamentiese tekste na die Nuwe-Testamentiese realiteit. Of die skool van Aleksandrië dit op allegoriese wyse, die skool van Antiochië dit letterlik, en Augustinus dit op 'n meer spirituele wyse probeer doen het, die vaste verwysingspunt het vas gestaan; net die wyse van hoe om daar uit te kom het verskil. Vir die letterlike skool van Antiochië het dit selfs die konsekwensies gehad dat indien die letterlike verstaan die saak sou bemoeilik, dan is die outensiteit van dusdanige tekste in die kanon bevraagteken (vgl Barrera 1998:528-535) 
Nie alleen interpreteer die Nuwe Testament die Ou Testament nie, maar doen dit ook in terme van interpretasiereëls wat veral in pseudo-epigrafiese geskrifte bekend is, daarom het die Nuwe Testament, in teenstelling met die Rabbynse tradisie, soveel voorkeur vir die apokaliptiese en die eindtye. Markus haal weer kwalik direk uit die Ou Testament aan, terwyl Matteus nie die geleenthede daarvoor kan laat verbygaan nie.

Vir ons doel hier is dit belangrik om daarop te wys dat die interpretasie wat in die Ou Testament beslag kry, steeds die teks vergesel het toe dit vertaal is na Grieks (die LXX). Die Griekse interpretasies is ook nie uniform nie en bevat interpretasies om aan eie voorkeure inslag te gee en om die verskillende geografiese en historiese kontekste te verreken. Cook (1997:211-223; 1999:139152) het byvoorbeeld aangetoon dat die Griekse vertaling van die Boek Spreuke meer konservatief deur 'n Aleksandrynse Jood vertaal is as die Hebreeuse teks, en ooreenstemmende interpretasies is aangebring waar die Hebreeuse teks te veel na Griekse idees geklink het. Naas die LXX het ook nog ander Griekse vertalings of resensies bestaan met onderlinge verskille, byvoorbeeld Symmachus, Aquila, Theodotion. Verder moet onthou word dat dit wat ons vandag as die Hebreeuse Bybel ken, in die vroeë Christelike en Rabbynse tradisies eerder die Griekse teks was. Dit is eers deur tekskritiek dat die sogenaamde eenheid van die Hebreeuse of die Masoretiese Teks gesoek is. Interpretasie is deel van die wordingsgeskiedenis van die teks en nie iets naas die teks nie. Mens kan eintlik saamstem met Gunn (1997:242-261) wanneer hy sê dat alle Bybelboeke deel is van multi-tekstualiteit en multi-kanonisiteit want in almal is verskille van interpretasie sigbaar en dié verskille het in verskillende kontekste kanonisiteitvoorkeure verkry.

Die bestaande Aramese vertalings en parafrases, die Targumim, wys duidelik dat die teks nie alleen vertaal is nie, maar dat interpretasie die teksproduksie vergesel. In Targum Neophyti word die opdrag aan Adam in Gen 2:15 om die tuin te bewerk en te bewaak, herinterpreteer en Adam word as 'n "Rabbi" voorgestel wat die Torâ moet bestudeer: "om in die Torâ te werk en stipulasies daarvan te bewaar" (vgl Barrera 1998:439). In Targum Pseudo-Jonathan verloop 
die debat tussen Kain en Abel heel anders as wat die Hebreeuse teks (Gen 4:8) meedeel: Die teks word uitgebrei om Abel as 'n proto-martelaar voor te stel en Kain as ' $n$ prototipe van ' $n$ afvallige aanklaer van die regverdige. ' $n$ Ellelange gesprek tussen Abel en Kain word ingevoeg. ${ }^{3}$

Op soortgelyke wyse is die apokriewe, die pseudepigrafiese geskrifte en die Qumran tekste, waaronder die oudste Hebreeuse tekste behoue gebly het, bewyse van die teks as geïnterpreteerde en interpreterende teks. Qumran het byvoorbeeld in die Habakukkommentaar (1QpHab) by wyse van die sogenaamde pešer-metode die gegewens van hierdie profeet op hulle afgesonderde gemeenskap van toepassing gemaak (vgl die vertaling in Martínez 1994:197202). Tekste is binne historiese werklikhede en beperkinge van die betrokke kontekste geïnterpreteer sonder die implikasie dat die interpretasie iets anders as die bestaande tekste sê. Korrekte interpretasie was nooit a-histories nie.

In die Rabbynse tradisie gaan die Mikra of Tanach altyd saam met interpretasie. Dit is nie 'n geval van die teks en daarnaas intepretasie daarvan nie. Dis twee gekoppelde kanons waarvan interpretasie net so 'n legitieme kanon is as die outoritatiewe teks self. Daar is geen verwysing dat die openbaring op een of ander manier onmiddelik of direk kan wees nie. Dit gaan altyd saam met die tradisie van interpretasie. Hierdie interpretasie is die waarborg dat die openbaring daadwerklik verstaan sal word in elke historiese moment.

Die Mishna, en by name die Talmud, het op hierdie wyse tot 'n komplekse interteks gegroei. 'n Bladsy van die Talmud bestaan uit Mishnah-kommentaar op 'n gedeelte van die Tanach, die Gamarah-tradisies, die Amorin-debate, kommen-

\footnotetext{
${ }^{3}$ Die vertaling lui: En Kain het vir sy broer Abel gesê: "Kom, laat ons albei in die veld gaan." En toe beide van hulle in die veld kom, sê Kain vir Abel: "Ek sien dat die wêreld deur liefde geskep is, maar dit word nie beheer deur die vrugte van goeie werke nie, want daar is voorkeurbehandeling in die oordeel. Waarom is jou offer met vreugde aanvaar en my offer nie met vreugde aanvaar nie?' Abel sê toe vir Kain: 'Die wêreld is deur liefde geskep en word regeer volgens die vrugte van goeie werke en daar is nie voorkeurbehandeling in die oordeel nie. Omdat die vrugte van my goeie werke beter en vroeër as joune was, is my offer met vreugde aanvaar.' Kain sê toe vir Abel: 'Daar is geen oordeel of regter, en geen ander wêreld nie; daar is geen beloning van goeie verdienste vir die regverdige nie en daar is geen straf vir die goddelose nie.' Abel antwoord toe vir Kain: 'Daar is oordeel en ' $n$ regter, en ' $n$ ander wêreld bestaan; daar is beloning van goeie verdienste vir die regverdige en straf vir die goddelose.' Op grond van hierdie woorde het hulle in die veld gestry. En Kain het teen sy broer opgestaan en 'n klip in sy voorkop gedryf en hom doodgemaak" (vgl die vertaling van Barrera 1998:440).
} 
taar van bekende geleerdes soos Rashi, byvoegings van die Tosafiste, Maimonides, en ander Rabbynse outoriteite. Alles op een bladsy! Hierdie "stemme" van die teks is nie uit een mond nie en is ook nie geharmonieer om mekaar presies na te spreek of te versoen nie. Die dialoog van kontinue interpretasie is hoorbaar en eintlik nooit afgesluit nie. Selfs indien dit oor 'n belangrike saak op 'n stemmery sou uitloop, is die minderheidsgesigspunt of verskil van die aanvaarde besluit nie buite orde nie. Die teks is die resultaat van interpretasie en die werklikheid van die teks is die realisering daarvan deur kontinue dialoog van historiese en kontemporêre stemme. Die betekenis van die teks word gerealiseer in die dialoog oor die probleem waarvoor 'n oplossing gevind moet word. Die teks verlaat op geen stadium die historisiteit daarvan nie omdat interpretasie dit telkens nuut realiseer.

Miskien is dit juis hierdie Rabbynse tradisie wat toonaagewende Joodse post-moderniste soos Bloom en Derrida tot die oortuiging gebruig het dat die teks refleksie van interpretasie is, eerder as houer van beteknis wat ontdek moet word (vgl Handelman 1982:xiv-xv).

\section{DIE OU-TESTAMENTIESE TEKS EN SUBVERSIE}

Om die argument verder te voer tot dit wat dikwels kategoriaal ontken word, naamlik dat die Bybelteks met sigself in teenspraak kan wees, word 'n klein seleksie van tekste geneem, naamlik Job en Jona. Beide hierdie tekste het sterk ondermynende trekke van ander tekste in die Bybel. Die begrip ondermyning word hier gebruik omdat die aanspraak hier gemaak word dat ondermyning tot doelbewuste strategie gemaak word. Die oogmerk is verder om die gevarieerdheid van die stemme van die Bybelteks van nader te bekyk as manifestasie van die teks as proses van interpretasie, en om dan later in aansluiting hierby by ' $n$ wyse van teksverstaan uit te kom wat tog wegbeweeg van die idee van teks as artefak of as 'n houer of kruik wat betekenis bevat. Die idee is ook om te ontkom aan die dwingelandy van die teks as objek van interpretasie wat aan die leser alleen die opsie bied om te ontdek wat daarin opgesluit lê, òf om agter te kom dit 
waaraan die teks die blote bestaan daarvan te danke het, naamlik dat dit toe verwys het na 'n vaste werklikheid buite sigself.

Daar is reeds gewag gemaak van verskillende tradisies en stemme in die Bybel en wat nie almal uit een mond spreek nie. As eerste teks van ondermyning word die teks van Job betrek

\subsection{Job en ondermyning}

Die teks van Job is minstens so laat as die Ballingskaptyd of Persiese tyd, met ander woorde die sesde eeu vC of later. Die tema van die twisgesprekke in die boek Job handel oor die verdedigbaarheid van 'n regverdige God ten aansien van die verwagtinge van 'n regverdige wat onregmatig ly. Die basiese tema was alombekend in die Nabye Ooste (vgl tekste soos Ludlul bel nemeqi, die Babiloniese Job, die Dialoog van 'n pessimis met sy siel) en die oplossing was altyd dat die oënskynlike lyding oortref sal word deur dubbelvoudige seën van die godheid. Om die bal aan die rol te sit, kies die "outeur" 'n dramatiserende dialoogteks waarin die verskillende sienings eie status en identiteit gegee word en nie die "outeur"/verteller se ouktoriële stem nie. Dit is reeds 'n eerste poging om van voorskriftelikheid of opdringerigheid weg te beweeg.

Verder neem die "outeur"/verteller die ouere "teologie" van die monargale wysheid en wat tipies was van die beoordeling van God se dade in die geskiedenis van Israel, byname dié van die Deuteronomis, waarna reeds verwys is. Die ouere wysheid, m.a.w voor Job, het soortgelyke idees gehuldig. Dit het daarop neergekom dat God se reg vergelykbaar is met 'n dogma van vergelding. Yahweh sal straf wat sleg is en wat goed is, sal hy beloon. Slegte dade is sigbaar vir die wyse manne en die gevolge is voorspelbaar. So ook is die oorsake voorspelbaar as die gevolge sigbaar is. 'n Mens kon die goddelike konsekwensie uit die aard van gedrag en handelinge aflei. Vir Job het hierdie teologie die konsekwensie gehad dat hy aan die verkeerde kant van die geluk van hierdie soort leer gestaan het. Met Job gaan dit ellendig en hy verloor, behalwe vir sy siek liggaam, alles. Dus moes hy iets vreesliks teen God gedoen het. Met hierdie moraliteit kom die teologie-vriende van Job hom aanspreek en "vertroos" soveel so dat Job voel hul woorde verbrysel hom (Job 19:2). Hierdie vriende is allermins karikature, daarvoor is die redenasies te eg verteenwoordigend van die gangbare teologie. Tog vind die verteller dit nodig om hierdie teologie/ideologie 


\section{Die Bybel: Teks en ondermyning}

deur die stem van Job te bevraagteken en eintlik te verwerp. Job hou vol dat hy nie onreg gepleeg het nie ${ }^{4}$, allermins nie sodanig dat wat hy nou ervaar proporsioneel is tot wat hy moontlik verkeerd kon gedoen het nie. Al verklaring is dat God self iets boos met hom beoog en dat God eintlik 'n soort boelie is wat bo enige regverdigbare rede sy aksies deurvoer (vgl Job 6:4, 16:12). So maak die teks die heersende teologie met God as subjek en waarborg van vergelding tot verleentheid. Doelbewus word die ouere teologie ondergrawe.

Die teks is egter nog meer ondermynend ten opsigte van die heersende antropologie. In die teks van Genesis (Gen 1:27-28) lees ons baie duidelik dat die mens as kroon van die skepping gemaak word. Die mens is die hoogtepunt van die skepping en die enigste wese na God se beeld, ook met die opgaaf om te heers oor die geskape plante- en dierelewe. Maar wanneer God op 'n magtige wyse Job uit die storms antwoord (Job 38-42) en Job blootgestel word aan God se siening van homself, dan verhang die bordjies (vgl Schmidt 2002:130-133). Job moet hoor dat God alleen die skepping daarstel en bestuur Job 38); alleen die flora en fauna onderhou en daaroor heers (Job 39); alleen mandaat oor die skepping het, en dat hy daarin van geen mens se hulp afhanklik is nie. Dat dit God is wat heer van die dierewêreld is en dat net hy die chaosdiere (die "dier" en "Leviatan"), waarop Hy eintlik trots is (vgl Nel 1991:206-226), kan tem en beheer (Job 40-41). Job is nie kroon van die skepping nie, hy is slaaf en 'n slawementaliteit van onderskikking pas hom. God het outonome reg, die mens het in die skepping 'n onderhorige rol waar die aansprake en uitsluitsel oor God se regverdigheid nie afgelees kan word nie. Prediker het hierdie ondermynende boodskap nog verder tuisgebring deur daarop te wys dat die mens aan die sikliese gang van tyd nie kan ontsnap nie, en dat hy/sy nooit die posisie van 'n heer/god van tyd kan inneem nie.

\subsection{Jona en ondermyning}

In die teks van Jona word ' $n$ mens met 'n erg ondermynende gegewe gekonfronteer. Waarskynlik is dit die mees onstellende teks in die Bybel. In die verhaal van Jona ontmoet ons 'n karakter wat sodanige probleme met die beste

\footnotetext{
${ }^{4}$ Job 29 is eintlik 'n klasieke verwoording van die hoogs denkbare etiek en moraliteit. As dit die lewensstyl van Job was, kon hy tereg hom op sy geregtigheid beroep ten aansien van beskuldigings (Job 6:24-30).
} 
eienskappe van God het dat hy besluit om eerder te sterf as om die pad saam met dié God te loop. As rede vir sy vlug van God en om nie God se oordeel in Nineve te gaan aankondig nie sê hy in Jona 4:2: "Ag, Here, ek het dit mos al in my land geweet. Daarom het ek reg in die begin na Tarsis gevlug. Ek weet $u$ is ' $n$ genadige en barmhartige God, lankmoedig en vol liefde; en berouvol oor die kwaad" (kursief: PJN). Hierdie vyf eienskappe van God kom in verskillende kombinasies ${ }^{5}$ in die Ou Testament voor en mens kan reken dat dit in die tyd van Jona deel was van die belydenis oor Yahweh wat in meer as een opsig die steunpilare van hul geloof was.

Jona, van beroep 'n profeet, en 'n Hebreër, het 'n lang pad saam met hierdie God geloop (1:9) maar uiteindelik het hierdie goeie eienskappe van God vir hom een te veel geword. Dit is waarom hy weier om die opdrag uit te voer. Dit is ' $n$ misplaaste voorstelling om Jona met ongehoorsaamheid te verbind. Gehoorsaamheid is nêrens in die teks ter sprake nie en ook nie in God en Jona se dialoog nie. Jona weier omdat hy 'n rede het, nie omdat hy ongehoorsaam is nie.

Verder is die gebeurekompleks (vgl Nel 1999:173-186) van die verhaal so saamgestel dat hierdie feit soos sout in rou wonde gevryf word. Op die skip waarmee hy probeer vlug (onttrek) van God, steek 'n storm op as manifestasie van hierdie dreigende God. Teenoor die matrose het dieselfde God weer eindelose genade. Soveel so dat die bedreigde skip vir hulle 'n heilsruimte word. Hulle bring ook sommer brandoffers daar op die skip aan 'n God wat hulle van te vore waarskynlik nie geken het nie (1:16). Arme Jona wat wens om te sterf, word nie eers 'n seegraf gegun nie!

In Nineve self loop Jona hom vas in 'n hiperboliese demonstrasie van God se genade en lankmoedigheid - presies wat hy geweet het sou gebeur. Die mees gevreesde Assiriese stad word heilsruimte vir die Israel- en Yahwehhatende inwoners wanneer mens en dier (sic!) vas en in rou gedompel word (3:7-

\footnotetext{
${ }^{5}$ In verskeie verse kom hierdie begrippe voor: Al vyf begrippe kom voor in Joël 2:13; 3 kom voor in Ps 86:15; 103:8; 145:8; Ex 34:6, 2 kom voor in Neh 9:17, 31; 2 Kron 30:9; Ps 111:4; 112:4; Num 14:18; Jon 3:9; in onmiddelike omgewing (bv Neh 3:13-17) en afsonderlik kom die begrippe ook dikwels voor.
} 
8). Vanselfsprekend giet God sy oormaat van berou en genade oor hulle uit. Maar vir Jona is die gebeure 'n beklemmende verwerping.

As hy dan verbitter buite die stad in die son sit, skiet daar 'n wonderplant op as skaduwee en Jona is terdeë bewus dat dit God se teenwoordigheid is en hy is met "' $n$ groot blydskap bly" daaroor (4:6), want minstens nou sien hy iets van God se genade ook vir hom. Maar wat gebeur dan: 'n wurm kom en vreet die plant en 'n warm wind verskroei dit net die volgende môre. Vir Jona, die persoon wat sy hele leeftyd met God loop, is die genade net 'n vinger lank! Geen wonder dat Jona in 'n monoloog nou besluit om eerder te sterf: "Dit is vir my beter om te sterf as om te leef" (4:8). Wanneer God dan wil weet of hy regtig rede het om so te voel, sê hy: "Ek het rede om vertoornd te wees tot die dood toe" (4:9). Dit is presies wat die verhaalgebeure van die vis ook wil sê, want in figuurlike sin is hy in die onderwêreld; soos die Hebreeuse teks inderdaad self sê $(2: 2,3,6)$. Sy belewing van God is so pynlik en so verwyderend dat dit vir hom voel hy is in die onderwêreld - die plek altyd verwyder van God. ${ }^{6}$

Dit is 'n ondermynende teks wat die karakter laat sterf oor die beste kwaliteite van God. Selfs die verteller is onseker oor hierdie aangeleentheid, omdat wanneer hy in die laaste reëls ook God stem gee as regverdiging, spreek dit nie Jona se diepste probleem aan nie, en laat hy ook God se woorde met 'n vraagteken in die lug hang - die enigste teks in die Bybel wat op 'n vraagteken eindig.

\section{TEKS AS DIALOGIESE GEBEURE}

Wat staan mens te doen met hierdie ondermynende Bybeltekste? Indien die Bybelteks ' $n$ objek is vir die bepaling van dogmas of presiese tekenvelde wat die werklikheid "nateken", dan sal mens verseker probleme met hierdie tekste hê. As hierdie tekstekens objetiewe werklikhede verteenwoordig, dan moet logiese teenstrydigheid die noodwendige konklusie wees vir die bestaan van subversiewe tekste. In terme van analitiese logika moet hierdie fragmente van onveranderlike openbaring lei tot die konklusie van teenstrydigheid as die

\footnotetext{
${ }^{6}$ Dit was ' $n$ algemene voorstelling in Israel dat die mens se grootste belewenis van nood voorgestel is as ' $n$ dood- of onderwêreldervaring, vgl bv Ps 88:4-5 en Ps 28:1.
} 
goddelike outeur 'n werklikheid sonder teenspraak deur die tekste sou kommunikeer, soos wat dit my lyk Van Rensburg en Potgieter voorstaan.

Daar is tog 'n ander uitweg ${ }^{7}$ uit die referensiële teorie van teksinterpretasie waarvolgens die teks na 'n vasstaande werklikheid verwys en waar die teks as houer van bepaalbare betekenis beskou word. Ook die Bybelteks kan nie na 'n onveranderlike werklikheid verwys, òf anders gestel, die Bybel kommunikeer nie 'n onveranderlike struktuur van die werklikheid nie. Dit is telkens historiese interpretasie en persepsie van wat as "struktuur" van die werklikheid verstaan word.

Vir ' $n$ ander uitweg is daar ' $n$ paar vereistes of voorwaardes. Eerstens moet aanvaar word dat ' $n$ teks net begin funksioneer as dit gelees (na geluister) word. Lees is die handeling wat betekenis toeskryf aan die teks. Betekenis word gerealiseer in die uitvoerende (performatiewe) handeling van lees. In 'n teater word die toneelstuk deur die opvoering eers toneelstuk, anders bly dit 'n teks. Die nosie van uitvoering/opvoering of die performatiewe dimensie van taal is te danke aan John Austin (1962). Hy het beklemtoon dat met taal en tekste iets gedoen word. Die uitvoerende of performatiewe taalhandeling verg deelname in die produksie van betekenis. Uitvoering en opvoering is nie, maar gebeur telkens, dit het ' $n$ verlede, ' $n$ hede en 'n toekoms. Dit geskied in tyd en tussen mense. As performatiewe handelinge het tekste iets bereik en in die leeshandeling kan dit nog steeds iets bereik. As veld van interpersoonlike kommunikasie kan dit nog altyd iets bereik. Alhoewel tekste nie absoluut verwys nie, het die taalhandelingsteorie dit darem vasgestel dat tekste dinge doen en dat in die kommunikatiewe situasie dit ook gebeur.

Vir die Bybelteks is dit dan eintlik verkeerd om te vra wat die teks sê of waarna dit verwys, en wat dit nog vandag beteken. Beter sou wees om te vra wat

7 Daar bestaan sekerlik ook ander opsies wat ontgin kan word in die soeke na lees- en interpretasiewyses wat ontkom aan die onmiddelike soeke na inhoud en die beslaglegging op interpretasie. "n Interesante opsie is om die begrip "skriftuur" (scripture) (vgl Kort 1996) deel te maak van teksteorie. Die kategorie van skriftuur verwys hier na die plasing of ligging in die tekstuele veld. Alle deelnemers van kultuur het en vind hul identiteit in relasie tot ' $n$ tekstuele veld waaruit daardie kultuur bestaan. Tekste is so deel van mense se skriftuur in terme van herinnering, antisipasie en aktuele ervaring. Tekste as deel van skriftuur het die vermoë om mense vorm, transformeer, maar ook te verwerp en ontdaan te maak van die sekerhede wat die omwêreld of kultuur bied. In hierdie konteks is die Bybelteks in terme van identiteit, betekenis en dinamiek in relasie tot ander tekste wat die skriftuur van subjekte binne ' $n$ bepaalde kultuur vorm, geen unieke teks nie. 
die teks bereik het in konkrete historiese kontekste en vandag nog bereik in die individuele en kollektiewe leeshandeling.

Sou mens dit toepas op die teks van Job en die subversiewe aard daarvan, kan die weg van dialoog met God moontlik word soos wat dit vir Job moontlik was, om ongeag die teenstrydighede en onbegryplikhede van God, tog nog 'n ontmoeting te kry. Dat slaaf van God dalk nie die slegste ding is wat kan gebeur nie, want dit open 'n ander sin van bestaan. By so 'n God kan al jou bitterspraak ook hoër aangeskryf staan as die beste teologie. Buite die gebaande kategorieë van denke en antwoorde van teologie, kan Job sy eie protes ontmasker en na nuwe dimensies van self en geloof as verworpeling uitreik (vgl Kort 1996:129).

In die allesvernietigende situasie en ontgogeling van die na-eksiliese tyd waar Israel alles verloor het en waar God sy eie volk harder gestraf het as enige ander heidenvolk, kon die Jona-teks mense die verpleterende werklikheid "aandoen" dat God oor die weg kan kom sonder die mense wat glo hulle verstaan hom. Hierdie teks moes hulle ruk tot stilstand om 'n pad te soek, want as hulle op die tipies Judese pad sou bly, was dood die voorland.

Maar ons sal tweedens ook altyd moet vashou daaraan dat tekste taal is en nooit aan taal kan ontsnap nie. Tekste kan nie hul linguale aard ontsnap nie. Hulle is produkte van noukeurige taal- en teksorganisasie. Mens kan hierdie taal as die grootste struikelblok sien van betekenisgenerering soos wat dit by Derrida word, maar dit kan ook die mees uitdagende speelveld wees van deelname aan betekenisskepping. Bybeltekste is produkte van literêre ontwerp, maar die topiek is so van lewensbelang dat dit die mens ook die alternatiewe humaniteit kan laat sien, waarvan Ricoeur (1980) praat. Daarom is self die keuse vir narratiwiteit ${ }^{8}$

\footnotetext{
${ }^{8}$ Dit blyk ook dat Hans Frei met sy begrip van "realistiese" literatuur van die Bybel en gepaardgaande letterlike lees van hierdie tekste, bedoel dat die betekenis van dié tekste nie geleë is in die historiese verwysings daarvan nie (gemik teen die historiese kritiek), ook nie in die toeeienning van die betekenis daarvan deur die leser nie (gemik teen die hermenutiese model), maar dat die openbaring van hierdie tekste deur die narratiewe vorm en inhoud van die tekste self gekommunikeer word. Die samehangende teks as geheel poog om die leser van die waarheid daarvan te oortuig (vgl die evaluering van Frei deur Poland 1985:120-137). Dit wil dus voorkom asof Frei ook die materiaal van die teks voorrang wil gee bo subjektiwiteit van die leser. In hierdie opsig is sy seining naby dié van Gadamer wat ook die waarheidspotensiaal van die teks handhaaf wat eers realiseer as die leser in verwagting en die regte antisipasie die teks lees om die oorvleueling van horisonne te bewerk.
} 
deel van die kommunikasiestrategie om die leser te betrek in die dinamiek van onbepaalde karakter, plot, ruimte en tyd. Alter (1992:27, 34, 40, 43-46) kon daarom sê dat narratiwiteit een van die suksesvolste kommunikasiemodi is om op 'n kreatiewe wyse oor die werklikheid van God te praat sonder om finaliteit daarop af te druk.

Derdens, sal ons altyd moet onthou dat die interaksie met tekste ons nooit in ' $n$ posisie plaas om finaal alles te begryp wat die teks gedoen het en steeds sal doen nie. Tekste is lewende entiteite, en verander gedurig soos wat hulle gelees word in verskillende historiese kontekste en hulle produseer telkens nuwe mutasies van hulle eie betekenis. Fokkelman (1999:26) sê: "In our naivety we fancy we have recognized what the text says, but what took place inside us is rather something like: we picked up a number of signals from the text and in our minds grouped these into a theme or point, without keeping an open mind for various signals not yet perceived. In this way, we have formed a picture of the whole which tends to become fixed."

Ons leeshandeling en die resultate daarvan is altyd provisioneel, al sou mens ook wou hê dat dit empiries die toets kan deurstaan. Die mate van adekwaatheid is die ooreensteming met medelesers oor wat die teks doen en nie waarna dit verwys nie. Hieroor moet die dialoog voortgaan. Die debat oor tekste en teksinterpretasie moet altyd dialogies wees, want tekste self is interpretasies en is ín kontinue prosesse van interpretasie. Hier bied die Rabbynse tradisie 'n besondere aanknopingspunt deurdat die tradisie van interpretasie net so deel is as die outoritatiewe teks self.

\section{SLOTOPMERKING}

Die Bybelteks sal beter baat as dit weer deel word van die leesgebeure van die individu en die religieuse kollektiwiteit en wanneer leesresultate in dialogiese konteks bly waar die absolute verwysing daarvan nie 'n soeke of eis is nie. 'n Teologie (vgl Hartmeier 2002:1-15) sal inderdaad orent kan kom gebaseer is op die performatiewe betekenis van Bybeltekste eerder as wat dit gebaseer op die absolute verwysings van tekste. 


\section{Literatuurverwysings}

Alter, R 1992. The world of biblical literature. New York: Basic Books.

Austin, J L 1962. How to do things with words. Cambridge, MA: Harvard University Press.

Barrera, J T 1998. The Jewish Bible and the Christian Bible, tr by W G E Watson. Leiden: Brill.

Beal, T K \& Gunn, D M 1997. Reading Bibles, writing bodies. London: Routledge.

Cook, J 1997. The law in Septuagint Proverbs. JNSL 23(1), 211-223.

Cook, J 1999. Contextual exegetical interpretations in the Septuagint Proverbs. JNSL 25(2), 139-152.

Deist, F E 1995. Canonical literature: Some ideological-critical observations. Acta Academica Suppl I, 66-78.

Degenaar, J 1995. The text as an episode in an all-encompassing textuality. Acta Academica Suppl I, 1-21.

Derrida, J 1978. Writing and difference, tr by A Bass. London: Routledge \& Kegan Paul.

Fish, S 1980. Is there a text in this class? The authority of interpretive communities. Cambridge, Mass: Harvard University Press.

Fokkema, D \& Ibsch, E 1992. Literatuurwetenskap en cultuuroverdracht. Muiderberg: Dick Coutinho.

Fokkelman, J P 1999. Reading Biblical narrative: An introductory guide. Louisville, Ky: John Knox Press.

Gunn, D M 1997. What does the Bible say? A question of text and canon in Beal \& Gunn 1997:242-261.

Handelman, S A 1982. The slayers of Moses: The emergence of Rabbinic interpretation in modern literary theory. Albany: State University of New York Press.

Hardmeier, C 2002. New relations between systematic theology and exegesis and the perspectives on practical theology and ethics. Ongepubliseerde referaat voorgedra by die OTWSA-Kongres, Stellenbosch, 12/09/2002, 1-15.

Hofmeyer, G 2002. N G Kerk 350:. Eenhonderd bakens in die geskiedenis van die Nederduitse Gereformeerde Kerk 152-2002. Kaapstad: NBD/Paarl Print

Kort, W A 1996. "Take, read": Scripture, textuality, and cultural practice. Pennsylvania: Pennsylvania State University Press.

Martínez, F G 1994. The Dead Sea Scrolls translated: The Qumran texts in English. Leiden: Bill.

Nel, P J 1991. Cosmos and chaos: A reappraisal of the divine discourses in Job 38-42. OTE 4(2), 206-226.

Nel, P J 1999. Arme Jona tussen teks en werklikheid. Skrif en Kerk 20(1), 173-186. 
Poland, L M 1985. Literary criticism and Biblical hermeneutics: A critique of formalists approaches. Chico: Scholars Press.

Potgieter, P C 2002. Hoe jy glo? Die Volksblad, 13/6/2002.

Ricoeur, P 1980. Essays in Biblical interpretation, ed with an introduction by L S Mudge. Philadelphia, PA: Fortress Press.

Spangenberg, S 2002. Drie beelde van Jesus. Rapport 23 Junie 2002.

Schmidt, N F 2002. Theophany and the divine discourses of Job. MA Verhandeling. Universiteit van die Vrystaat.

Vanhoozer, $\mathrm{K} \mathrm{J}$ 1998. Is there a meaning in this text? Grand Rapids, MI: Zondervan. Van Rensburg, J Janse 2002. Ek laat dit aan prof Durand oor. Die Volksblad, 19 September 2002. 